\title{
Analysis of the cephalometric pattern of Brazilian achondroplastic adult subjects
}

Renato Cardoso', Sergio Ajzen², Aline Ribeiro Andriolo ${ }^{3}$, Jefferson Xavier de Oliveira ${ }^{4}$, Adagmar Andriolo ${ }^{5}$

Objective: The aim of this study was to assess the position of the cranial base, maxilla, and mandible of Brazilian achondroplastic adult subjects through cephalometric measurements of the cranio-dento-facial complex, and to compare the results to normal patterns established in literature. Methods: Fourteen achondroplastic adult subjects were evaluated based on their radiographic cephalometric measurements, which were obtained using the tracings proposed by Downs, Steinner, Bjork, Ricketts and McNamara. Statistical comparison of the means was performed with Student's $t$ test. Results: When compared to normal patterns, the cranial base presented a smaller size in both its anterior and posterior portions, the cranial base angle was acute and there was an anterior projection of the porion; the maxilla was found to be smaller in size in both the anteroposterior and transversal directions, it was inclined anteriorly with anterior vertical excess, and retropositioned in relation to the cranial base and to the mandible; the mandible presented a normal-sized ramus, a decreased body and transverse dimension, a tendency towards vertical growth and clockwise rotation, and it was slightly protruded in relation to the cranial base and maxilla. Conclusion: Although we observed wide individual variation in some parameters, it was possible to identify significant differences responsible for the phenotypical characteristics of achondroplastic patients.

Keywords: Achondroplasia. Measures. Cephalometry. Maxillofacial abnormalities.

Objetivo: avaliar o tamanho e o posicionamento da base do crânio, da maxila e da mandíbula de indivíduos acondroplásicos brasileiros adultos, a partir de medidas cefalométricas do complexo dentoesqueletofacial. Confrontar os dados obtidos aos padrões de normalidade estabelecidos na literatura. Métodos: foram avaliados 14 indivíduos acondroplásicos adultos, utilizando algumas grandezas cefalométricas radiográficas obtidas a partir dos traçados preconizados por Downs, Steinner, Björk, Ricketts e McNamara. Para análise estatística, foi aplicado o teste $t$ de Student na comparação de médias. Resultados: em relação aos padrões de normalidade estabelecidos, a base craniana apresentou dimensões diminuídas, tanto na porção anterior quanto na posterior. O ângulo da base craniana apresentou-se agudo e houve projeção anterior do pório. A maxila apresentou dimensões menores no sentido anteroposterior e transversal, anteroinclinada, excesso vertical anterior e retroposicionada em relação à base do crânio e da mandíbula. A mandíbula apresentou ramos com dimensão normal e redução nas dimensões do corpo e transversal, tendência de crescimento vertical e rotação no sentido horário, discretamente protruída em relação à base do crânio e da maxila. Conclusão: ainda que tenha sido observada ampla variação individual em alguns dos parâmetros, foi possível identificar diferenças significativas responsáveis pela apresentação fenotípica característica dos pacientes acondroplásicos.

Palavras-chave: Acondroplasia. Circunferência craniana. População padrão. Desenvolvimento maxilofacial.

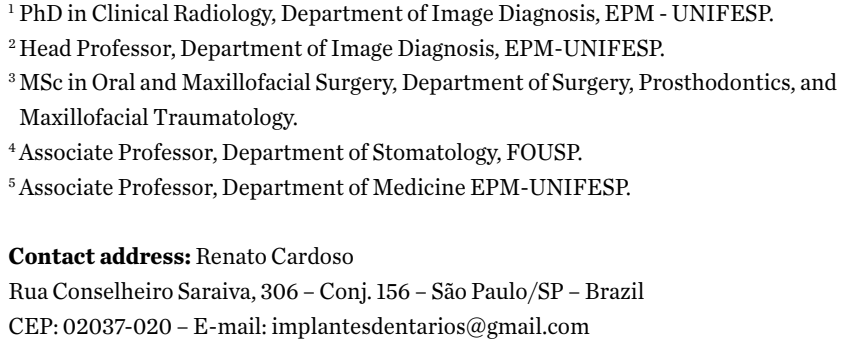

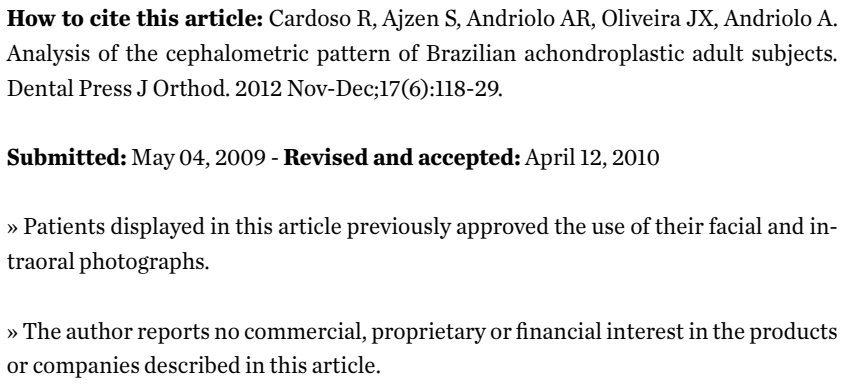

How to cite this article: Cardoso R, Ajzen S, Andriolo AR, Oliveira JX, Andriolo A. Analysis of the cephalometric pattern of Brazilian achondroplastic adult subjects. Dental Press J Orthod. 2012 Nov-Dec;17(6):118-29.

Submitted: May 04, 2009 - Revised and accepted: April 12, 2010

» Patients displayed in this article previously approved the use of their facial and intraoral photographs.

" The author reports no commercial, proprietary or financial interest in the products or companies described in this article. 


\section{INTRODUCTION}

The term achondroplasia was first used by Parrot in 1878, and it refers to the most common form of dwarfism caused by the shortening of the limbs. Its estimated prevalence is between $1 / 26.000$ and $1 / 56.000$ born alive, ${ }^{29}$ and it occurs in both sexes equally. ${ }^{24,37}$ It is autosomal dominant condition, ${ }^{19}$ occurring sporadically by substitution of the amino acid glycine for the amino acid arginine in position 380 , in the transmembrane region of the fibroblast growth factor receptor 3 (FGFR-3). ${ }^{41}$ The substitution of cysteine for glycine in position 375 of the same protein region has also been described. ${ }^{45}$ The FGFR3 is responsible for bone growth and remodeling, and it acts by regulating chondrocytic proliferation in the cartilage growth plate. When mutated, it loses this ability, causing a reduction in endochondral bone formation. ${ }^{48}$ The intramembranous and periosteal bone formations take place normally, leading the patients to present a striking phenotype on account of the underdevelopment of the appendicular skeleton, with various deformities of the lower limbs and an increased cephalic perimeter. ${ }^{6,36}$ Hydrocephalus may also be observed. ${ }^{6,22,23,35}$

The typical facies is characterized by a voluminous skullcap. . $, 6,8,13,22,23,28,36,42,47,49$ with a prominent frontal boss and a wide, flattened and depressed nasal bridge, a prominent occipital bone and an increased volume of the frontal and sphenoidal sinuses. ${ }^{8,27}$
The cranial base may present with a decreased size $^{1,6,16,25,28,35,38}$ due to the premature closure of the spheno-occipital synchondrosis., ${ }^{8,22,23,42}$.

All of the dimensions ${ }^{6,16,22,23,25,28,29,38,42,47,49}$ of the maxilla may be reduced, and it may be retruded in relation to the cranial base. ${ }^{8,13}$ The mandible may be prognathic $c^{1,13,22,23,28,29,35,49}$ or with a relative anterior projection, ${ }^{8,38}$ with diastemas in the lower teeth. ${ }^{47}$

There are few cephalometric studies on achondroplastic subjects, and most of them are isolated clinical case reports with often incomplete morphologic analyses.

Based on the radiographic cephalometric measurements obtained using the lateral analyses of Downs, ${ }^{11,12}$ Steiner, ${ }^{44}$ Bjork, $^{3}$ Ricketts $^{32}$ and McNamara, ${ }^{26}$ and the frontal analysis of Ricketts, ${ }^{33}$ we have thus evaluated the anterior and posterior cranial base, the maxilla and the mandible, and the relationship of the facial structures with the cranial base and with each other in achondroplastic subjects, and compared the data obtained with normal patterns observed in the literature.

\section{MATERIAL AND METHODS}

The sample of this study consists of frontal and lateral cephalometric radiographs of 14 Brazilian achondroplastic adult subjects. Six of them were male and eight were female, with ages between 18 and 53 years.
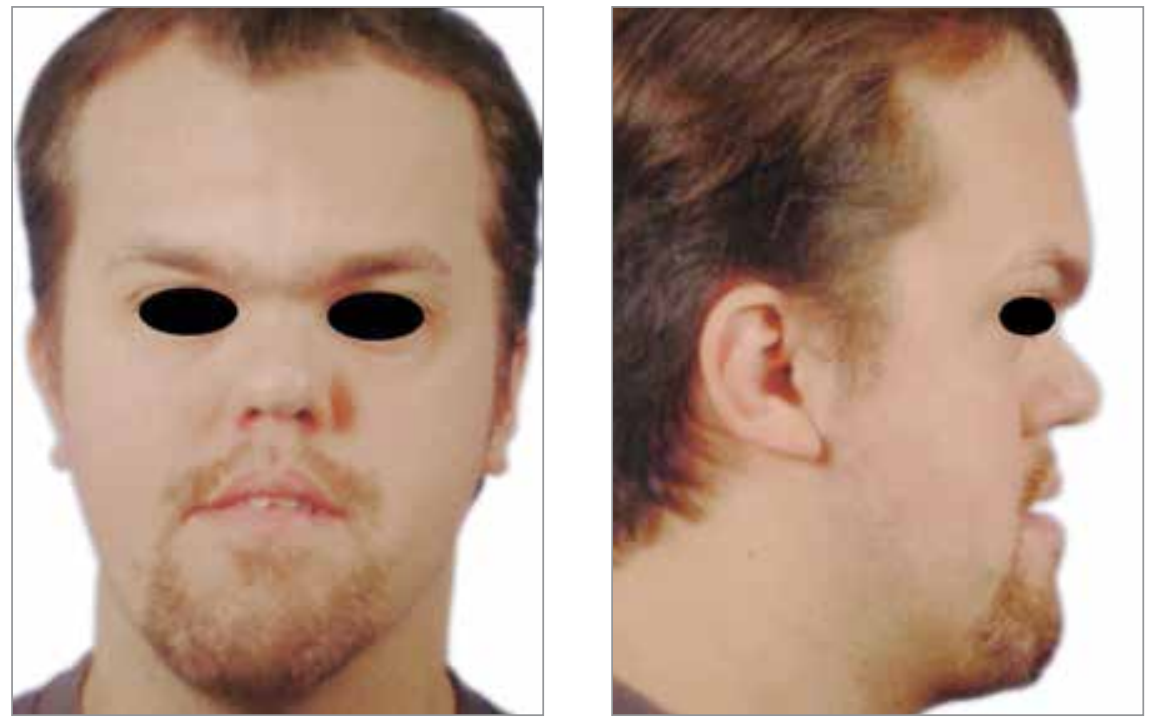

Figure 1 - Facial frontal view. 


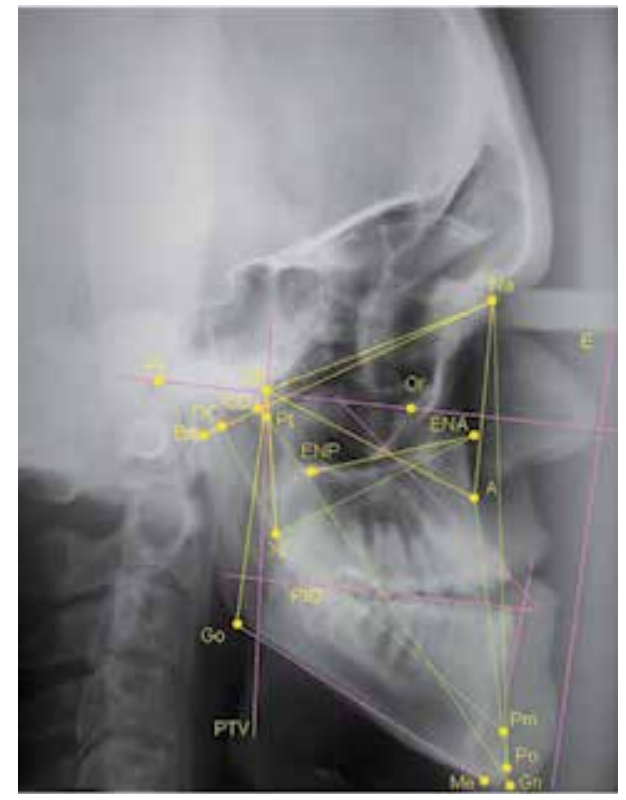

Figure 2 - Facial lateral view.

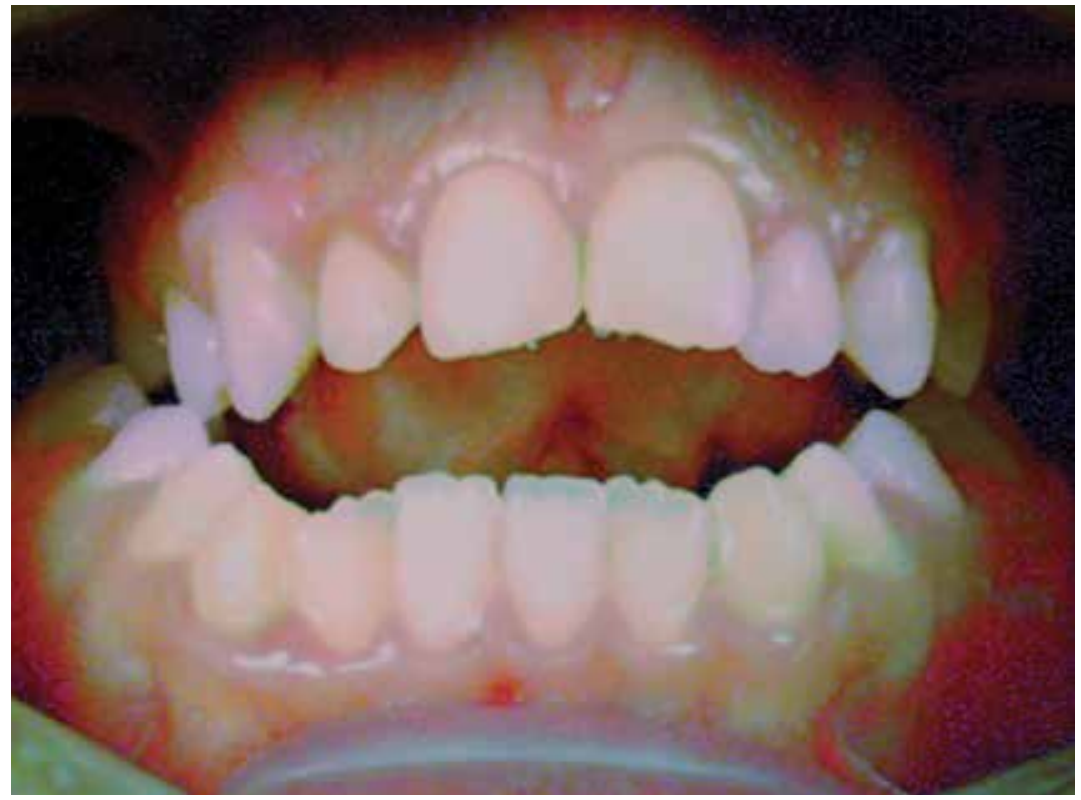

Figure 3 - Characteristic malocclusion.
The lateral and frontal cephalometric radiographs were taken according to the technique proposed by Broadbent ${ }^{4}$ and Ricketts. ${ }^{33}$ For correct evidencing of the soft tissue profile on the radiographic image, an aluminum filter was attached to the film holder, according to the technique described by Freitas. ${ }^{16}$

Cephalograms were traced over each radiograph using some of the linear and angular measurements of Downs', ${ }^{11,12}$ Steiner's, ${ }^{44}$ Bjork's, ${ }^{3}$ Ricketts ${ }^{32,33}$ and McNamara's ${ }^{26}$ analyses.

The angular measurements were recorded in degrees and obtained using a protractor, with a precision of 1 degree. The linear measurements were recorded with a millimeter ruler, accurate to the nearest $0.5 \mathrm{~mm}$. Approximations of $0.5^{\circ}$ and 0.25 $\mathrm{mm}$ were made during the measurements.

To verify the precision of the method, all measurements were made independently by two examiners, in two different moments. The $t$ test for two samples was performed for the measurements obtained by one examiner in relation to the same measurements obtained by the second one. The results indicated that there were no significant differences between measurements, with $\mathrm{p}<0.01$.

Statistical analysis was performed with Student's $t$ test for small samples, to compare the mean values obtained for the achondroplastic subject with normal values. We used the two-tailed test because we did not know whether the mean values of our sample would be larger or smaller than the clinical norm. The level of significance was set at $5 \%$.

\section{RESULTS}

The results obtained are presented in Tables 1,2 and 3 . The values presented are the clinical norm, the mean, standard deviation, and statistical significance degree of each one of the parameters studied. Table 1 shows the data obtained from the profile cephalometric analysis. Table 2 shows the individual results obtained from McNamara's lateral cephalometric analysis. ${ }^{19}$ For each value found for the individual measurements of maxillary length there is a corresponding value of reference for mandibular length and anterior facial height. Table 3 shows data obtained from Ricketts' frontal cephalometric analysis. 
Table 1 - Lateral cephalometric analysis.

\begin{tabular}{|c|c|c|c|c|c|c|c|c|}
\hline Factor & Clinical Norm & Mean & $\begin{array}{l}\text { Standard } \\
\text { Deviation }\end{array}$ & Minor Value & Major Value & obtained $\mathbf{t}$ & critical t 0.05 & $\mathbf{p}$ \\
\hline Molar relation & $-3.0 \pm 3.0 \mathrm{~mm}$ & -3.05 & 2.80 & -8.90 & 0.70 & -0.0666 & \pm 2.1788 & ns \\
\hline Canine relation & $-2.0 \pm 3.0 \mathrm{~mm}$ & 1.33 & 2.80 & -4.90 & 5.00 & 4.1276 & \pm 2.1788 & $p<0.005$ \\
\hline Overjet & $2.5 \pm 2.5 \mathrm{~mm}$ & 2.67 & 3.96 & -4.30 & 12.10 & 0.1397 & \pm 2.2010 & ns \\
\hline Overbite & $2.5 \pm 2.0 \mathrm{~mm}$ & -1.22 & 2.98 & -6.10 & 2.50 & -4.1396 & \pm 2.2010 & $p<0.005$ \\
\hline Lower incisor extrusion & $1.3 \pm 2.0 \mathrm{~mm}$ & 0.97 & 1.97 & -2.20 & 5.00 & -0.5814 & \pm 2.1788 & ns \\
\hline Interincisal angle & $130.0 \pm 6.0^{\circ}$ & 118.41 & 8.60 & 107.20 & 132.20 & -4.4692 & \pm 2.2010 & $p<0.005$ \\
\hline Convexity & $1.0 \pm 2.0 \mathrm{~mm}$ & -1.15 & 4.79 & -8.30 & 8.30 & -1.6196 & \pm 2.1604 & ns \\
\hline Facial height & $47.0 \pm 4.0^{\circ}$ & 53.61 & 7.97 & 37.80 & 72.00 & 2.9906 & \pm 2.1604 & $p<0.025$ \\
\hline First molar position & $21.0 \pm 3.0 \mathrm{~mm}$ & 21.39 & 4.84 & 12.60 & 28.90 & 0.2808 & \pm 2.1788 & ns \\
\hline Lower incisor protrusion & $1.0 \pm 2.0 \mathrm{~mm}$ & 7.57 & 3.00 & 0.70 & 12.00 & 7.5979 & \pm 2.1788 & $p<0.005$ \\
\hline Upper incisor protrusion & $3.5 \pm 2.0 \mathrm{~mm}$ & 10.45 & 3.20 & 5.80 & 16.00 & 7.5240 & \pm 2.1788 & $p<0.005$ \\
\hline Lower incisor inclination & $22.0 \pm 4.0^{\circ}$ & 28.78 & 6.20 & 16.80 & 36.10 & 0.4338 & \pm 2.1788 & ns \\
\hline Upper incisor inclination & $28.0 \pm 4.0^{\circ}$ & 32.82 & 4.44 & 26.10 & 38.90 & 3.7662 & \pm 2.1788 & $p<0.005$ \\
\hline Occlusal plane to ramus & $-4.0 \pm 3.0 \mathrm{~mm}$ & -4.82 & 4.88 & -13.30 & 3.00 & -0.6068 & \pm 2.1604 & ns \\
\hline Occlusal plane inclination & $27.0 \pm 4.0^{\circ}$ & 27.66 & 3.90 & 22.20 & 33.70 & 0.6076 & \pm 2.1604 & ns \\
\hline Labial protrusion & $-4.0 \pm 2.0 \mathrm{~mm}$ & -0.39 & 4.06 & -6.70 & 7.20 & 3.2067 & \pm 2.1604 & $p<0.01$ \\
\hline Upper lip length & $24.0 \pm 2.0 \mathrm{~mm}$ & 33.64 & 4.67 & 25.20 & 41.70 & 7.4513 & \pm 2.1604 & $p<0.005$ \\
\hline Lip commissure & $-3.0 \mathrm{~mm}$ & -4.31 & 5.81 & -12.00 & 9.60 & -0.8155 & \pm 2.1604 & ns \\
\hline Facial depth & $90.0 \pm 3.0^{\circ}$ & 89.60 & 4.09 & 82.80 & 96.70 & -0.3528 & \pm 2.1604 & ns \\
\hline Facial axis & $90.0 \pm 3.0^{\circ}$ & 87.25 & 5.02 & 77.90 & 94.00 & -1.9756 & \pm 2.1604 & ns \\
\hline Facial cone & $68.0 \pm 3.5^{\circ}$ & 61.36 & 4.94 & 51.90 & 66.70 & -4.8429 & \pm 2.1604 & $p<0.005$ \\
\hline Mandibular plane & $24.0 \pm 4.0^{\circ}$ & 29.12 & 5.53 & 21.70 & 39.00 & 3.3362 & \pm 2.1604 & $p<0.01$ \\
\hline Maxillary depth & $90.0 \pm 3.0^{\circ}$ & 88.23 & 4.93 & 80.00 & 95.30 & -1.2968 & \pm 2.1604 & ns \\
\hline Maxillary height & $57.0 \pm 3.0^{\circ}$ & 55.76 & 2.44 & 53.10 & 61.20 & -1.8246 & \pm 2.1604 & ns \\
\hline Palatal plane & $1.0 \pm 3.5^{\circ}$ & 5.76 & 5.10 & -4.30 & 13.30 & 3.3613 & \pm 2.1604 & $p<0.01$ \\
\hline Total facial height & $60.0 \pm 3.0^{\circ}$ & 63.14 & 6.98 & 51.20 & 77.00 & 1.6239 & \pm 2.1604 & ns \\
\hline Cranial deflection & $27.0 \pm 3.0^{\circ}$ & 28.84 & 2.59 & 25.00 & 32.00 & 2.5689 & \pm 2.1604 & $p<0.025$ \\
\hline Anterior cranial length & $63.0 \pm 2.5 \mathrm{~mm}$ & 58.64 & 3.31 & 52.70 & 65.00 & -4.7499 & \pm 2.1604 & $p<0.005$ \\
\hline Posterior facial height & $65.0 \pm 3.3 \mathrm{~mm}$ & 64.71 & 3.68 & 56.50 & 71.00 & -0.2871 & \pm 2.1604 & ns \\
\hline Mandibular ramus position & $76.0 \pm 3.0^{\circ}$ & 79.79 & 6.48 & 71.40 & 96.00 & 2.1107 & \pm 2.1604 & ns \\
\hline Articular cavity position & $-46.0 \pm 2.2 \mathrm{~mm}$ & -31.79 & 19.63 & -49.30 & 34.00 & 2.6104 & \pm 2.1604 & $p<0.025$ \\
\hline Mandibular arch & $31.0 \pm 4.0^{\circ}$ & 29.18 & 6.06 & 19.00 & 39.00 & -1.0845 & \pm 2.1604 & ns \\
\hline Mandibular body length & $81.0 \pm 2.5 \mathrm{~mm}$ & 73.41 & 7.67 & 62.60 & 86.40 & -3.5681 & \pm 2.1604 & $p<0.005$ \\
\hline Occlusal plane inclination & $0.0 \pm 2.0 \mathrm{~mm}$ & -0.04 & 1.95 & -2.70 & 3.00 & -0.0793 & \pm 2.1604 & ns \\
\hline F.NP & $88^{\circ}$ & 89.06 & 3.48 & 82.80 & 95.20 & 1.1042 & \pm 2.1604 & ns \\
\hline NAP & $0^{\circ}$ & -1.41 & 9.00 & -15.50 & 15.80 & -0.5663 & \pm 2.1604 & ns \\
\hline SNA & $82^{\circ}$ & 82.31 & 3.16 & 77.30 & 88.90 & 0.3585 & \pm 2.1604 & ns \\
\hline SNB & $80^{\circ}$ & 83.22 & 5.76 & 71.40 & 92.00 & 2.0166 & \pm 2.1604 & ns \\
\hline ANB & $2^{\circ}$ & 0.11 & 4.53 & -9.00 & 7.00 & -1.5015 & \pm 2.1604 & ns \\
\hline SND & $76^{\circ}$ & 80.14 & 6.02 & 67.30 & 89.00 & 2.4765 & \pm 2.1604 & $p<0.05$ \\
\hline NS.PIO & $14^{\circ}$ & 10.31 & 7.35 & -2.90 & 28.00 & -1.8075 & \pm 2.1604 & ns \\
\hline NS.GoGn & $32^{\circ}$ & 36.47 & 4.79 & 29.70 & 46.50 & 3.3671 & \pm 2.1604 & $p<0.01$ \\
\hline GoGn.PIO & $18^{\circ}$ & 26.22 & 6.03 & 14.50 & 35.60 & 4.9186 & \pm 2.1604 & $p<0.005$ \\
\hline 1/.NA & $22^{\circ}$ & 40.74 & 27.21 & 23.00 & 128.00 & 2.3855 & \pm 2.1788 & $p<0.05$ \\
\hline 1/-NA & $4 \mathrm{~mm}$ & 11.36 & 4.82 & 5.70 & 24.00 & 5.2916 & \pm 2.1788 & $p<0.005$ \\
\hline$/ 1 . N B$ & $25^{\circ}$ & 27.70 & 8.14 & 12.90 & 43.20 & 1.1492 & \pm 2.1788 & ns \\
\hline$/ 1-N B$ & $4 \mathrm{~mm}$ & 7.52 & 2.70 & 2.90 & 11.60 & 4.5144 & \pm 2.1788 & $p<0.005$ \\
\hline H.NB & 9 to $12 \mathrm{~mm}$ & 8.39 & 5.53 & -0.70 & 22.10 & -1.3788 & \pm 2.1604 & ns \\
\hline H-NARIZ & 9 to $11 \mathrm{~mm}$ & 3.81 & 5.81 & -6.30 & 13.10 & -3.8410 & \pm 2.1604 & $p<0.005$ \\
\hline $\mathrm{P}-\mathrm{NB}$ & $0 \mathrm{~mm}$ & 0.35 & 2.18 & -3.90 & 3.80 & 0.5792 & \pm 2.1604 & ns \\
\hline Mental eminence & $8 \mathrm{~mm}$ & 9.04 & 2.92 & 3.20 & 15.30 & 1.2896 & \pm 2.1604 & ns \\
\hline $\mathrm{S}-\mathrm{N}$ & $78 \pm 3.0 \mathrm{~mm}$ & 70.64 & 2.62 & 66.00 & 74.00 & -10.1259 & \pm 2.1604 & $p<0.005$ \\
\hline $\mathrm{S}-\mathrm{Ar}$ & $36.5 \pm 3.0^{\circ}$ & 27.00 & 4.04 & 23.00 & 35.00 & -8.4820 & \pm 2.1604 & $p<0.005$ \\
\hline N.S.Ar & $130.0 \pm 5.0^{\circ}$ & 117.29 & 10.00 & 99.00 & 134.00 & -4.5862 & \pm 2.1604 & $p<0.005$ \\
\hline A-Nperp & 0 to $1 \mathrm{~mm}$ & -1.69 & 3.71 & -8.40 & 4.80 & -2.1333 & \pm 2.1604 & ns \\
\hline A vertical - upper incisor & 4 to $6 \mathrm{~mm}$ & 10.32 & 4.04 & 4.40 & 20.00 & 4.7545 & \pm 2.1604 & $p<0.005$ \\
\hline Lower incisor - A-Po & 1 to $3 \mathrm{~mm}$ & 7.94 & 2.77 & 1.80 & 13.00 & 7.7221 & \pm 2.1604 & $p<0.005$ \\
\hline Pogonion - Nperp & -2 to $2 \mathrm{~mm}$ & -1.86 & 7.20 & -14.90 & 12.30 & -0.9335 & \pm 2.1604 & ns \\
\hline Mandibular plane angle & $22^{\circ}$ to $25^{\circ}$ & 29.90 & 4.92 & 23.00 & 39.00 & 4.6935 & \pm 2.1604 & $p<0.005$ \\
\hline
\end{tabular}

ns $=$ not statistically significant. 
Table 2 - McNamara composed norms.

\begin{tabular}{|c|c|c|c|c|c|c|c|c|}
\hline \multirow{2}{*}{$\begin{array}{l}\text { Patient } \\
\text { Name }\end{array}$} & \multicolumn{2}{|c|}{ Maxillary length } & \multicolumn{2}{|c|}{ Mandibular length } & \multicolumn{2}{|c|}{ Maxillomandibular differential } & \multicolumn{2}{|c|}{ Facial anteroinferior height } \\
\hline & Gender & $\begin{array}{l}\text { obtained } \\
\text { value }\end{array}$ & $\begin{array}{l}\text { expected } \\
\text { value }\end{array}$ & $\begin{array}{l}\text { obtained } \\
\text { value }\end{array}$ & $\begin{array}{l}\text { expected } \\
\text { value }\end{array}$ & obtained value & $\begin{array}{l}\text { expected } \\
\text { value }\end{array}$ & $\begin{array}{l}\text { obtained } \\
\text { value }\end{array}$ \\
\hline KMHP & Female & 78.9 & 97 a 100 & 118.7 & 18 a 21 & 39.7 & 57 a 58 & 79.7 \\
\hline PRDS & Female & 80.8 & 99 a 102 & 116.9 & 18 a 21 & 36.0 & 57 a 58 & 77.3 \\
\hline SCG & Female & 74.0 & 97 a 100 & 112.8 & 18 a 21 & 38.8 & 57 a 58 & 79.9 \\
\hline CLL & Female & 86.0 & 97 a 100 & 121.1 & 18 a 21 & 35.1 & 57 a 58 & 75.4 \\
\hline MPC & Female & 88.8 & 112 a 115 & 109.3 & 23 a 26 & 20.5 & 62 a 64 & 77.6 \\
\hline MAPC & Female & 84.7 & 105 a 108 & 110.3 & 18 a 21 & 25.6 & 60 a 62 & 73.1 \\
\hline FCF & Female & 88.4 & 97 a 100 & 122.9 & 23 a 26 & 34.5 & 57 a 58 & 70.7 \\
\hline MRHP & Female & 82.7 & 103 a 106 & 122.7 & 20 a 23 & 39.9 & 58 a 59 & 73.4 \\
\hline GSS & Male & 77.0 & 130 a 133 & 134.0 & 18 a 21 & 57.0 & 57 a 58 & 97.0 \\
\hline$A C$ & Male & 91.7 & 117 a 120 & 129.2 & 25 a 28 & 37.5 & 64 a 65 & 83.3 \\
\hline HASGF & Male & 83.2 & 103 a 106 & 112.4 & 20 a 23 & 29.2 & 58 a 59 & 70.3 \\
\hline HDSP & Male & 78.0 & 97 a 100 & 126.1 & 19 a 22 & 48.1 & 57 a 58 & 88.5 \\
\hline LFDC & Male & 81.2 & 99 a 102 & 141.4 & 18 a 21 & 60.2 & 57 a 58 & 96.0 \\
\hline IRDA & Male & 99.5 & 130 a 133 & 127.3 & 30 a 33 & 27.8 & 70 a 74 & 75.0 \\
\hline
\end{tabular}

Table 3 - Ricketts frontal analysis.

\begin{tabular}{|c|c|c|c|c|c|c|c|c|}
\hline Factor & Clinical Norm (mm) & Mean & $\begin{array}{l}\text { Standard } \\
\text { Deviation }\end{array}$ & Minor Value & Major Value & $\begin{array}{c}\text { t } \\
\text { obtained }\end{array}$ & t critical 0,05 & $\mathbf{p}$ \\
\hline Nasal width & $32.0 \pm 2.0$ & 31.95 & 3.24 & 28.50 & 38.80 & -0.0556 & \pm 2.1604 & ns \\
\hline Nasal height & $53.0 \pm 3.0$ & 48.54 & 2.43 & 42.20 & 52.10 & -6.6340 & \pm 2.1604 & $p<0.005$ \\
\hline Maxillary width & $67.0 \pm 3.0$ & 62.16 & 6.88 & 52.30 & 77.50 & -2.5379 & \pm 2.1604 & $p<0.025$ \\
\hline Mandibular width & $89.3 \pm 3.0$ & 84.82 & 6.01 & 76.30 & 97.70 & -2.6887 & \pm 2.1604 & $p<0.025$ \\
\hline Facial width & $137 \pm 3.0$ & 128.71 & 8.00 & 114.00 & 145.10 & -3.7364 & \pm 2.1604 & $p<0.005$ \\
\hline
\end{tabular}

ns = not statistically significant.

\section{DISCUSSION}

To present our observations more effectively, this chapter will be divided into separated sections that will examine the results related to the cranial base, maxilla, and mandible. The measurements are expressed in proper form of mean values and standard deviation.

\section{The cranial base}

To assess the cranial base we used the parameters described by Ricketts, ${ }^{32}$ which were related to anterior cranial length, cranial deflection, and Porium location (Pr). These parameters have not yet been described in literature for achondroplastic subjects' analysis. We also used other parameters already evaluated by some authors and described by Bjork, ${ }^{3}$ such as the $\mathrm{S}-\mathrm{N}$ distance to assess the anteri- or cranial base $(78.0 \pm 3.0 \mathrm{~mm})$, and $\mathrm{S}-\mathrm{Ar}(36.5 \pm 3.0$ $\mathrm{mm}$ ) to assess the posterior cranial base. The relationship between anterior and posterior bases and their growth direction was assessed through sella angle measurement (N-S-Ar).

The anterior cranial length (CC-Na) shows the degree of development of the middle- facial third in the anteroposterior direction. ${ }^{31}$ In our sample, the mean value for the anterior cranial length was $58.6 \pm 3.3 \mathrm{~mm}$, with amplitude from 52.7 to 65.0 $\mathrm{mm}$, which suggests deficient growth of the anterior cranial base.

The S-N distance measurement presented by Bjork $^{3}$ also evaluates the length of the anterior cranial base. The clinical norm value is $78.0 \pm$ $3.0 \mathrm{~mm}$ in the adult. In the studied group, we observed mean values of $70.6 \pm 2.6 \mathrm{~mm}$, varying from 
66.0 to $74.0 \mathrm{~mm}$. All patients were below clinical norm, confirming that the growth pattern is abnormal, as already observed with CC-Na. Therefore, we can assert that the achondroplastic subjects studied have an abnormal growth pattern of the anterior cranial base, resulting in reduction of its final length. This is in disagreement with $\mathrm{Cohen}^{8}$ and Bjork $^{3}$ findings.

Considering the endochondral origin of cranial base bones and that endochondral bone formation is modified in achondroplasia, it is expected that hypoplasia and shortening of the cranial base occur. Several authors ${ }^{5,6,14,19,22,23,25,38,42,47}$ believe that the entire cranial base is smaller in achondroplasia. However, Rubin ${ }^{35}$ and McKusick $^{28}$ assert that only the anterior portion is reduced, while Mueller ${ }^{27}$ and Funaki ${ }^{17}$ believe that only the posterior portion exhibits reduced length.

The zone between the foramen caecum and the pituitary fossa presents endochondral and sutural bone growth. The area between the foramen caecum and nasium grows in length by bone apposition and by the development of the frontal sinus. However, in radiological cephalometry, these two areas are studied together by measuring the magnitude of $\mathrm{S}-\mathrm{N}$, this represents a combination of different growth forms. ${ }^{18}$ Since in achondroplasia the endochondral growth is different and the volume of the frontal sinus is increased, ${ }^{27}$ it would be more appropriate to study these areas independently. Thus, a smaller length between fossa pituitary and foramen ceacum would be observed which, occasionally, may be concealed due to the cephalometric magnitude analyzed $(\mathrm{S}-\mathrm{N})$ that has two different kinds of bone growth.

The compensatory growth, either for bone apposition, frontal sinus growth, or neural growth, would not be enough to compensate the deficient endochondral growth; this explains the shortened cranial base observed in our sample.

In our study, it was used the S-Ar measurement to assess the length of the posterior cranial base. It was observed a mean value of $27.0 \pm 4.0$ $\mathrm{mm}$, and all cephalograms studied presented values smaller than the normal established pattern $(27.0 \pm 4.0 \mathrm{~mm})$, confirming findings published by Cohen $^{8}$ and Bjork. ${ }^{3}$
Finding an extremely short posterior cranial base in achondroplasia makes biological sense, because, as previously mentioned, the cranial base is preformed from cartilage and it is the endochondral bone formation that is affected in this condition. The growth of the posterior base takes place, primarily, in spheno-occipital synchondrosis, with some bone apposition at the anterior edge of the foramen magnum. Most growth deficiencies in the posterior length of the cranial base, in achondroplasia, result from a lack of adequate growth in spheno-occipital synchondrosis. The closure of this synchondrosis is observed between eleven and sixteen years old. Studies performed by Cohen $^{8}$ indicated that the closure takes place before the age of eight or nine years old in achondroplastic subjects. Thus, hypoplasia of the posterior cranial base may result from early closure of sphenooccipital synchondrosis in achondroplastic, when compared to normal subjects.

To assess the curvature of the cranial base we used the N.S.Ar angles and cranial deflection.

Due to the endochondral growth in sphenoidal synchondrosis, the angle of the cranial base (N.S.Ar) undergoes a gradual increase of around $14^{\circ}$, during the $10^{\text {th }}$ to $14^{\text {th }}$ weeks of pregnancy. Then, it remains steady for a fetal lifetime and with values close to $130^{\circ} .{ }^{39}$ We noted that the N.S.Ar reference values are, on average, significantly smaller than the normal values $\left(117.0 \pm 10.0^{\circ}\right)$, showing a prominent curvature of cranial base when compared to the reference values. Studied authors who describe this cephalometric measurement in achondroplasia confirm this reduction. . $3,8,20,27,35^{2}$

The cranial base angle is much more acute in achondroplastic than in normal subjects. The clivus has an almost vertical orientation. Alterations in the curvature of the normal cranial base are argued to be both pre- and postnatal. ${ }^{2,3,15,39} \mathrm{It}$ is known that the cranial base curvature degree in human is larger than in other primates in account of the increased brain size and the early closure of intersphenoidal synchondrosis. ${ }^{29}$ The greater closure of the angle of the cranial base in achondroplasia may be related to increased brain size and, maybe, to the premature closure of intersphenoi$\mathrm{dal}^{39}$ and spheno-occipital synchondrosis. 
The cranial deflection, not yet referred in the literature to analyze achondroplastic subjects, determines the spatial orientation of the cranial base, demonstrating basal and skeletal dysplasia. In our study, we observed mean values of $28.8 \pm 2.6^{\circ}$, which are statistically significant in relation to the clinical norm. These data confirm the distinguished decrease in the cranial base angle, with deficient posterior cranial base growth, as previously demonstrated by the evaluation of both the posterior cranial base length (S-Ar) and the sella angle (N.S.Ar).

Porium location (Pr) should be analyzed together with cranial deflection, indicating the temporal bone joint cavity position, and, therefore, the mandibular condyle implantation site. A Pr anterior location is associated to Class III growth, leading to an anterior mandible positioning. This measurement, associated to others, contributes to determine the mandibular growth pattern and its anteroposterior positioning. The mean values we observed were $-31.8 \pm 19.6 \mathrm{~mm}$. This demonstrates Pr significant anterior positioning in relation to the normal pattern. This is probably due to reduced posterior cranial base growth, and increased cranial base curvature. The temporomandibular joint protruded in relation to the cranial base, projecting the mandible forward, possibly explaining the Class III profile found in facial analysis of the greatest part of achondroplastic subjects studied.

\section{The maxilla}

Concerning the maxilla size in achondroplasia, the majority of the authors ${ }^{6,8,10,19,22,23,25,29,38,42,47,49}$ believe that these subjects present a reduced maxilla. Rubin, ${ }^{35}$ however, relates normal dimensions for all facial bones.

In our sample, we observed that the maxillomandibular differential was increased in 12 of 14 studied cases, with increased mandibular effective length. Since the mandibular effective length is a reference value for the maxillary length, ${ }^{26}$ we found, through posterior facial height and mandibular body length measurements, that the mandible was decreased in size, on average. Thus we consider the maxilla to be reduced in at least 12 of 14 cases.
The exact role of cartilage in facial development is not well defined. Some authors consider facial cartilage as inductors of primary growth, which is intrinsically regulated. Others believe that facial cartilage is completely passive and adaptive. For Koski ${ }^{21}$ both points of view are partial and mistaken, but his findings of a retracted midfacial third in achondroplasia add support to the facial cartilage intrinsic role, since cartilage preformed bone is hypoplasic in achondroplasia.

A concern for our study was to analyze the maxilla position in relation to the cranial base, the face, and the mandible. To assess maxilla anteroposterior direction, we used linear (facial convexity and A-Nperp) and angular (SNA and maxillary depth) measurements, and to assess the upper-lower direction we used palatine plan and maxillary height.

We could verify that most cases (8 from 14) presented a negative convexity value, with mean value and standard deviation of $-1.2 \pm 4.8 \mathrm{~mm}$. The maxillas were slightly retropositioned, and very close to normal, representing a very subtle Class III skeletal maxillary profile. This value is not statistically significant, and the amplitude ranged from 8.3 to $-8.3 \mathrm{~mm}$, with great inter-individual variability.

We found $88.2 \pm 4.9^{\circ}$ as the mean values to maxillary depth, showing slightly Class III skeletal maxillary profile. These values associated to those obtained to convexity determination lead us to conclude that the maxillary positioning was, on average, close to normal or slightly retracted.

Beyond these parameters, SNA angle measurement revealed a mean value of $82.3 \pm 3.2^{\circ}$, corresponding to an adequate position of the maxilla in relation to the cranial base. This confirms a maxillary anteroposterior position tendency similar to normal pattern, as seen in the convexity measurements and maxillary depth. However, if we consider that we observed a decreased cranial base in both posterior and anterior portions, we can assert that the $\mathrm{N}$ point may be retropositioned, showing a more retracted maxilla.

In our sample, the mean value and standard deviation of A-Nperp were $-1.7 \pm 3.7 \mathrm{~mm}$, which indicates a retruded maxillary position (though not statistically significant). Nine of the fourteen patients studied presented negative values; the amplitude 
ranged from -8.4 to $4.8 \mathrm{~mm}$, showing increased variability of this parameter among patients. Nperp is, usually, a safe line of orientation to determine maxillary position. An exception is Class III malocclusion, in which the anterior cranial base is a small, ${ }^{26}$ as we also observed. In this case, the retracted position of the $\mathrm{N}$ point results in construction of an incorrect Nperp. This will give both the maxilla and the mandible an excessively anterior positioning appearance. ${ }^{26}$ In our analysis, the studied subjects presented anterior cranial base growth smaller than the normal pattern; thereby we consider that the $\mathrm{N}$ point is retracted. This associated with the Class III clinical facial profile increases the importance of the negative mean value observed.

Through this method, when evaluating the values obtained for convexity, maxillary depth, SNA, and A-Nerp, we observe the maxilla, on average, wellpositioned tending to retroposition. The anterior cranial base growth was reduced, as this parameter is the reference for the anteroposterior maxillary position, we conclude that there is a clear tendency to maxillary anteroposterior deficient growth.

We should consider that point A might vary, depending on the location of the upper incisor. If its crown is excessively palatally-inclined, point A would be displaced toward the buccal axis, owing to the inclination of the root apex. ${ }^{26}$ The upper incisor position in relation to its respective bone base is analyzed by calibrating its inclination, which was increased, on average, turning point A into a reliable reference.

In our study, we noticed that the maxilla was inclined anteriorly, with the palatal plane angle mean value of $5.8 \pm 5.1^{\circ}$, which was statistically significant. This finding also characterizes the skeletal anterior opened bite observed in the analysis of 9 out of 14 patients. This finding is in agreement with Cohen's studies, ${ }^{8}$ who believes that the frequency of infections in hearing tubes, and the speech characteristic of achondroplastic patients are affected by the anteroposterior inclination of the nasal floor.

We observed that there was, on average, a prevalence of reduced angles $\left(55.8^{\circ}\right)$ on maxillary height, which may represent a vertical excess of the maxilla, in association with mandibular clockwise rotation tendency and increased lower face.
The assessment of transversal growth was performed from frontal cephalometric radiograph measurements. To assess maxillary width and its relationship with the mandible, we used the measurement of the maxillary width from Ricketts frontal analysis. ${ }^{25}$ We note that the mean value of maxillary width was significantly reduced $(62.2 \pm 6.9 \mathrm{~mm})$ in relation to the clinical norm $(67.0 \pm 3.0 \mathrm{~mm})$, showing deficient transversal maxillary growth. This finding was confirmed by the presence of uni- or bilateral crossbite, clinically observed in 8 out of 14 subjects.

We observed a significant reduction in facial width in the majority of studied subjects (mean value of $128.7 \pm 8.0 \mathrm{~mm}$ ), representing reduced transverse facial growth, following the deficient transverse maxillary growth.

Considering the alterations in linear measurements (facial convexity, A-Nperp, and maxilla width), and angular measurements (SNA, maxillary depth, palatal plane inclination, and maxillary height) we conclude that the maxilla of the studied achondroplastic subjects were smaller in the transverse and anteroposterior directions, slightly retropositioned, and inclined forward in relation to the cranial base.

Many reports in the literature state that achondroplastic subjects present a typical pattern characterized by a depressed nasal bridge and prominent frontal bone. . $6,13,14,19,22,23,24,28,35,36,38,42,43,49$ These observations are understandable when it is remembered that the external border of frontal bone presents appositional growth, while nasal bones, in spite of arising from the suture due to bone apposition, depend directly on nasal septum cartilaginous growth. ${ }^{39}$

Our study did not analyze the sizes of frontal and nasal bones, as there is a consensus broadly argued in the literature. We chose to assess the size of the nasal cavity through the data obtained from Ricketts frontal cephalometry analysis, namely: Nasal width and height. This analysis is unique with reference to achondroplastic subjects. They may present respiratory physiologic deficiencies, due to narrowing of the nasal cavity.

The mean value of nasal width found in our sample was $32.0 \pm 3.2 \mathrm{~mm}$, showing normal growth of the nasal cavity in the transversal direction, despite the 
maxillary and facial deficient transversal growth. The mean value of nasal height was $48.5 \pm 2.4 \mathrm{~mm}$, revealing deficient height growth of the nasal cavity, which may be related to shortening of the midface. Therefore we surmise that the anterior inclination of the nasal cavity floor and palatal plane is due to the deficient maxillary anterior vertical growth.

Thus, we conclude that the nasal cavity had normal size in the horizontal direction and was reduced in the vertical direction. The normal horizontal growth of the nasal cavity was not expected because the maxilla had reduced horizontal dimensions.

Other studies will be necessary to analyze nasal respiratory function and its clinical implications in achondroplastic patients.

\section{The mandible}

Concerning the mandible we analyzed size, growth direction, and position in relation to the maxilla and the cranial base.

The mean value of mandibular body length was $73.4 \pm 7.7 \mathrm{~mm}$, with statistical significance demonstrating deficient growth.

The mean value of posterior facial height was $64.7 \pm 3.7 \mathrm{~mm}$. In spite of observing a well-developed mandibular ramus, the presence of anterior opened bite was observed in 9 of 14 analyzed patients, suggesting no association with an underdeveloped mandibular ascending ramus.

The mandibular arc presented a mean value of $29.2^{\circ}$, demonstrating a balanced growth direction between mandibular body and ramus; however, the mandibular body has an anterior inclination tendency, and open goniac angle. Regarding the goniac angle, Funaki ${ }^{17}$ believes that achondroplastic subjects had a greater value for this cephalometric measurement.

The analysis of mental eminence in the horizontal direction showed that the mean value of the mentum size was $9.0 \pm 2.9 \mathrm{~mm}$, very similar to the normal value $(8.0 \mathrm{~mm})$; therefore, we conclude that there was no excessive horizontal or deficient growth of the mentum, and its size is not related to relative mandibular prognathism.

Increased mandibular plane values, as found in our sample $\left(29.1 \pm 5.5^{\circ}\right)$, frequently indicate short ramus and dolicofacial pattern. As observed through the mean value of posterior facial height and mandibular arc, the mandibular ramus presented normal height; however, we can confirm the mandibular growth tendency towards clockwise rotation. This justifies menton vertical excess and increased lower facial height.

The mean value observed for the facial axis angle was $87.3 \pm 5.0^{\circ}$, not statistically significant in relation to normal pattern, suggesting a balanced growth vector, with a vertical tendency. The SN.Gn angle also represents the vector resulting from mandibular growth, indicating whether growth is predominantly horizontal, vertical or harmonic. The clinical norm is $67.0^{\circ}$ and the mean values found in the studied group were $65.2^{\circ}$, not statistically significant. This indicates harmonic mandibular growth predominance, with tendency towards vertical growth. We observed statistically significant values in the facial cone angle (mean $61.4^{\circ}$ ), corroborating the facial tendency towards vertical growth.

When evaluating SN.PlO angle, we observed slightly reduced values (mean $10.3^{\circ}$ ) in relation to the clinical norm $\left(14.0^{\circ}\right)$, showing an acceptable relation between the occlusal plane and the anterior cranial base. We observed significantly increased angles in the relations between the occlusal plan and the mandibular base (GoGn.PlO); and between the mandibular base and the cranial base (SN.GoGn). We observed mean values and standard deviation of $26.2 \pm 6.0^{\circ}$ for the GoGn.PIO angle, and for the SN.GoGn angle the values were $36.5 \pm 4.8^{\circ}$ respectively; we concluded that the mandible has clockwise growth tendency, with menton vertical increase, what justifies the menton vertical excess. This finding supports the observations of Caffey ${ }^{6}$ and Funaki, ${ }^{17}$ who describe these patients as long face subjects.

When observing the mandibular length, measured from condyle point (Cd) to gnatium ( $\mathrm{Gn}$ ), we observed that 12 of 14 patients presented values greater than the established norm. However, McNamara's analysis ${ }^{26}$ does not consider isolated values; he idealized the composed norms: a relation among maxillary length, mandibular length, and facial anterior lower height. So, since mandibular growth deficiency is verified through the measurement of mandibular body length, and mandible size is increased in relation to the maxilla, we deduce 
that the size of the maxilla is much reduced in the analyzed cases. Moreover, the increase of facial anterior-lower height confirms mandibular vertical growth with clockwise rotation.

The mandibular width is represented by the AG-GA distance, verified in Ricketts frontal cephalometric analysis. ${ }^{33}$ The clinical norm is $89.3 \pm 3.0 \mathrm{~mm}$ in the adult; we observed significantly smaller values in the cephalograms studied $(84.8 \pm 6.0 \mathrm{~mm})$, which represents a deficient mandibular transversal growth.

Our results suggest statistically significant reduced values for the mandibular body length and width in the achondroplastic subjects studied. The mandibular ramus length, assessed through facial posterior height (clinical norm: $65.0 \pm 3.3 \mathrm{~mm}$, and mean value obtained: $64.7 \pm 3.7 \mathrm{~mm}$ ), was within normal values. The same occurred to the values of mandibular arc, facial axis angle, and SN.Gn angle. This demonstrated a balanced growth direction between the ascending ramus and mandibular body, but with tendency towards vertical growth, sustained by the increase in mandibular plane angle, a great decrease in the facial cone angle, and the increase in both GoGn.PlO and SN.GoGn angles.

Significant differences in ramus length or mandibular body were not observed in Cohens ${ }^{8}$ studies. However, he found significant difference in gonial angle value between normal and achondroplastic subjects - but he credited the finding to the small size of the studied sample.

Although Meckels cartilage determines the format of the mandible in development, it is totally reabsorbed soon after birth. ${ }^{21}$ The greatest part of the mandible develops membranous bone and, therefore, it is not expected in achondroplastic patients to exhibit growth alterations. The condylar cartilage results from mesenchymal cell condensation as secondary cartilage, next to the condylar ossification process. They combine with each other and are completely separated from Meckel's cartilage. The histological organization and biochemical composition of condylar cartilage are different from endochondral growth. ${ }^{21}$ Cohen ${ }^{8}$ suggests that the normal mandible size in achondroplasia may represent a different kind of condylar cartilage, which grows appositionally instead of interstitially, as in the chondrocranium. Since the achondroplastic gene hits only the interstitial cartilage growth, then it will not reach the mandible.

However, we believe that the observed deficient growth of both mandibular transverse dimension and body may be related to deficient mandibular symphysis cartilage growth, which undergoes total resorption only after the first year of life,${ }^{46}$ and it may be changed by the FRGr-3 deficiency that is present in achondroplasia. ${ }^{41,45,48}$ Histological studies are necessary to confirm this hypothesis.

For the evaluation of mandibular position, we used several measurements. Facial depth is determined by the intersection of the facial plane and horizontal Frankfurt plane. It is the same measurement used in Downs analysis ${ }^{11,12}$ to indicate mandibular anteroposterior position. In our sample, we could verify that there was no statistically significant difference between the observed value $\left(89.6 \pm 4.0^{\circ}\right)$ and the clinical norm $\left(90.0 \pm 3.0^{\circ}\right)$. This indicates a wellpositioned mandible in the anteroposterior direction, and represents a mesofacial pattern.

We measured the Po-Nperp distance to assess the relation between the mandible and the cranial base; the clinical norm was -2.0 to $+2.0 \mathrm{~mm} \cdot{ }^{26}$ Values greater than $2.0 \mathrm{~mm}$ indicate that the mandible is positioned anteriorly in relation to the cranial base. In our study, we observed great variation among patients, with amplitude from -14.9 to $12.3 \mathrm{~mm}$. From these, six patients presented a retropositioned mandibles, with mean value of $-8.1 \pm 5.3 \mathrm{~mm}$; three patients presented anteropositioned mandibles, in which the mean value was $6.5 \pm 5.1 \mathrm{~mm}$; four patients exhibited values within the interval defined by the clinical norm $0.62 \pm 1.2 \mathrm{~mm}$.

We assessed the mandibular position in relation to cranial base through two other angles: SNB and SND.

SND angle is less susceptible to mechanical actions; therefore, it is more reliable than the SNB angle. ${ }^{44}$ We observed that both SNB and SND presented values greater than the clinical norm, $83.2^{\circ}$ and $80.1^{\circ}$, respectively (only SND was statistically significantly different from the norm). These parameters also showed large individual variation, with amplitude of $71.4^{\circ}$ to $92.0^{\circ}$ for SNB angle, and $67.3^{\circ}$ to $89.0^{\circ}$ for SND angle. These data confirm the anterior mandibular positioning tendency. 
The mandibular ramus position is assessed through the angle between Frankfurt and CF-Xi planes. In our sample, we observed a mean value of $79.8 \pm 6.5^{\circ}$, statistically significantly increased in relation to the clinical norm. The Class III pattern may be related to anterior ramus positioning, represented by an increased angle, as observed in our sample.

Porion location (Pr) determines the TMJ position in the anteroposterior direction, and, in association with mandibular ramus position, can assist the diagnosis of skeletal pattern. The values we observed were statistically significant $(-31.8 \pm 19.6 \mathrm{~mm})$, demonstrating TMJ anterior positioning when compared to the normal profile. Although the vertical growth of the mandibular ramus is normal, and the body length is decreased, the Pr anterior positioning projects the mandible forward. So, mandibular prognathism does not occur due to excessive mandibular growth, but mostly because of the anterior projection of the mandible as a whole, due to the anterior displacement of the joint cavity and mandibular condyle.

It has been emphasized in the literature that achondroplastic subjects are characterized by relative mandibular prognathism. 1,714,19,22,23,28,30,37,38,49 Many authors believe that maxillary retropositioning is responsible for the relative mandibular prognathism observed. $5,24,29,35,36,40,43$ Basing our conclusions on Bjork's studies, ${ }^{2}$ mandibular prognathism may oc- cur due to the smaller cranial base angle (S.N.Ar) observed in achondroplastic subjects. The mandibular prognathism seems to be, as well, a consequence of maxillary retraction in relation to the cranial base. However, the mandible, despite presenting reduced body, is located more ventrally in relation to the anterior portion of the cranial base.

\section{CONCLUSION}

Considering the results obtained in this study, we concluded that it is possible to identify significant differences responsible for the phenotypical characteristics of achondroplastic patients despite the wide individual variation observed:

1. The cranial base was smaller in both anterior and posterior portions, with acute cranial base angle and anterior projection of the temporal bone joint cavity;

2. The maxilla was smaller in anteroposterior and transverse directions, and was inclined forward, with anterior vertical excess, and retropositioned in relation to the cranial base and to the mandible;

3. The mandible presented a normal-sized ramus; decreased body and transverse size; tendency towards vertical growth and clockwise rotation; and is slightly protruded in relation to the cranial base and maxilla. 


\section{REFERENCES}

1. Bailey JA. Orthopedic aspects of achondroplasia. J Bone Jt Surg. 1970;52A(7):1285-301.

2. Bjork $A$. The face in profile: an anthropological $x$ ray investigation on Swedish children and conscripts. Am J Orthod. 1948;34(8):691-9.

3. Bjork A. Cranial base development. Am J Orthod. 1955;41(3):198-225.

4. Broadbent $\mathrm{BH}$. A new $\mathrm{X}$-ray technique and its application to orthodontics. Angle Orthod. 1931;1(2):45-66

5. Brook $A H$, Winter GB. Dental anomalies in association with achondroplasia. $\mathrm{Br}$ Dent J. 1970;129(11):519-20.

6. Caffey J. Achondroplasia. In: Kelley VC. Brennerman's practice of pediatrics. Hagerstown: W. F. Prior; 1957. p. 1-22.

7. Chiba S, Abe S, Ohmori I. Oral manifestations of achondroplasia: a case report Tsururni Shigaku. 1976;2(1):35-43.

8. Cohen MM, Walker GF, Ceib F. A morphometric analysis of the craniofacial configuration in Achondroplasia. J Craniofac Genet Dev Biol Suppl. 1985;1:139-65.

9. Cohen MM. Achondroplasia, hypochondroplasia and thanatophoric dysplasia: clinically related skeletal dysplasias that are also related at the molecular level. Int J Oral Maxillofac Surg. 1998;27(6):451-55.

10. Dorsch C. Orthodontic examination of children with growing anomalies. Stomat DDR. 1978;28(4):237.

11. Downs WB. Variations in facial relationships: their significance in treatment and prognosis. Am J Orthod. 1948;34(10):812-40

12. Downs WB. Analysis of the dentofacial profile. Angle Orthod. 1956;26:191-212.

13. Dunbar JP, Goldin B, Subtelny JD. Correction of Class I crowding in an achondroplastic patient. Am J Orthod Dentofacial Orthop. 1989;96(3):255-63.

14. Elfenbaum BA. Oral manifestations of dwarfism. Dent Dig. 1967;73(4):178-80.

15. Ford EHR. Growth of the human cranial base. Am J Orthod. 1958;44(7):498-506.

16. Freitas PA. Telerradiografia: filtro para destacar perfil de partes moles. Bol Soc Paul Orthod. 1966;4(2):17-9.

17. Funaki J, Motohashi N, Noguchi K. The change of craniofacial growth of 2 patients with achondroplasia. J Jap Stomat Soc. 1984;51(3):551-61.

18. Goose DH, Appleton J. Human dentofacial growth. Oxford: Pergamon Press; 1982.

19. Gorlin RJ, Pindborg JJ, Cohen MM Jr. Syndromes of the head and neck. $2^{\text {nd }}$ ed. New York: McGraw Hill; 1976. p. 12-6.

20. Jolly RJ, Moore WJ. Skull growth in achondroplasic (cn) mice; a craniometric study. J Embryol Exp Morphol. 1975;33(4):1013-22.

21. Koski K. Cranial growth centers: facts or fallacies. Am J Orthod. 1968;54(8):566-83

22. Langer LO Jr, Baumann PA, Gorlin RJ. Achondroplasia. Am J Roentgenol Radium Ther Nucl Med. 1967;100(1):12-26.

23. Langer LO Jr, Baumann PA, Gorlin RJ. Achondroplasia: clinical radiologic features with comment on genetic implications. Clin Pediat. 1968;7(8):474-85.

24. Langer LO Jr, Rimoin DL. Achondroplasia. In: Bergsma D. Birth defects compendium. $2^{\text {nd }}$ ed. New York: National Foundation; 1979. p. 34-5.

25. McDonald RE. Dentistry for the child and adolescent. $2^{\text {nd }}$ ed. St. Louis: Mosby; 1974.

26. McNamara JA. A method of cephalometric evaluation. Am J Orthod. 1984;86(6):449-69.
27. Mueller SM, Bell W, Cornell S, Hamsher KS, Dolan K. Achondroplasia and hydrocephalus. Neurology (Minneap). 1977;27:430-4.

28. Mckusick VA. Achondroplasia: a genetic and statistical survey. Ann Hum Genet. 1970;33(3):227-44.

29. Oberklaid F, Danks DM, Jensen F, Stace L, Rosshander S. Achondroplasia and hypochondroplasia. J Med Genet. 1979;16(2):140-6.

30. Ponseti IG. Skeletal growth in achondroplasia. J Bone Joint Surg Am. 1970;52(4):701-16.

31. Ricketts RH. A cephalometric synthesis. Am J Orthod. 1960;46(9):647-73.

32. Ricketts RH. Cephalometric analysis and synthesis. Angle Orthod. 1961;31(3):141-56.

33. Ricketts RH. Perspectives in the clinical application of cephalometrics. Angle Orthod. 1981;51(2):115-50.

34. Rimoin DL, Hughes G, Kaufman RL, Rosenthal RE. Endochondral ossification in achondroplastic dwarfism. N Engl J Med. 1970;283:728-35.

35. Rubin P. Dynamic classification of bone dysplasias. Chicago: Year Book Medical; 1964

36. Ruppe C. Pathologie de la bouche. $6^{\text {th }}$ ed. Paris: J.B. Bailliere; 1931. p. 170-1.

37. Salmon MA, Lindenbaum RH. Developmental defects and syndromes. Aylesbury: HM \& M; 1978. p. 246-8.

38. Salzmann JA. Practice of orthodontics. Philadelphia: J.B. Lippincott; 1966. v. 1, p. $333-40$.

39. Scott JH. Dentofacial development and growth. Oxford: Pergamon Press; 1967. 205 p.

40. Shafer WG, Hine MK, Levy BM. Patologia bucal. 3a ed. Rio de Janeiro: Interamericana; 1979. p. 548-50.

41. Shiang R, Thompson LM, Zhu YZ, Church DM, Fielder TJ, Bocian M, et al. Mutations in the transmembrane domain of FGRF3 cause the most common genetic form of dwarfism, achondroplasia. Cell. 1994;78(2):335-42.

42. Smith DW, Jones KL. Recognizable patterns human malformation: genetic, embryologic and clinical aspects. $3^{\text {rd }}$ ed. Philadelphia: Saunders; 1982. p. 248-51.

43. Stafne EC, Gibilisco JA. Diagnóstico radiológico em odontologia. Buenos Aires: Panamericana; 1978.

44. Steiner C. Cephalometric for you and me. Am J Orthod. 1953;39(10):729-55.

45. Superti-Furga A, Eich G, Bucher HU, Wisser J, Giedion A, Gitzelmann R. A glycine 375-to-cysteine substitution in the transmembrane domain of fibroblast growth factor receptor-3 in a newborn with achondroplasia. Eur J Pediatr Mar. 1995;154(3):215-9.

46. Torres R. Biologia de la boca: estrutura y función. Buenos Aires: Panamericana; 1973.

47. Trapnell DH, Bowerman JE. Dental manifestations of systemic diseases. London: Butterworth; 1973.

48. Wilkin DJ, Szabo JK, Cameron R, Henderson S, Bellus GA, Mack ML, et al. Mutations in fibroblast growth-factor receptor 3 in sporadic cases of achondroplasia occurs exclusively on the paternally derived chromosome. Am J Hum Genet. 1998:63(3):711-6.

49. Zegarelli EV, Kutscher AH, Hyman GA. Diagnosis of diseases of the mouth and jaws. Philadelphia: Lea \& Febiger; 1969. 